\title{
Clonal Arabica coffee resistant to Meloidogyne paranaensis and damage threshold on
}

\section{plants development}

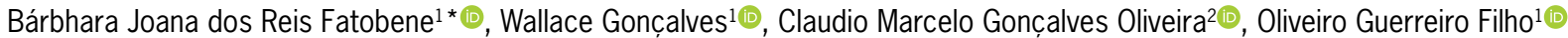

1Instituto Agronômico, C.P. 28 - 13020-902 - Campinas, $\mathrm{SP}$ - Brasil.

Instituto Biológico, C.P. 70 - 13001-970 - Campinas, SP - Brasil.

*Corresponding author <barbhara.fatobene@gmail.com>

Edited by: Roy Neilson

Received December 06, 2017

Accepted February 06, 2018

\begin{abstract}
Plants of Coffea arabica Icatu IAC 925 germplasm show resistance to Meloidogyne paranaensis under field conditions, but with variable rates of segregation. One mother plant, IAC 3 , of Icatu IAC 925 was evaluated under controlled conditions through the reaction of its clones, obtained by somatic embryogenesis. Reproduction of nematodes in clones were compared with an open-pollinated progeny from the same mother plant, C. arabica cultivar Mundo Novo IAC 515-20, susceptible to nematodes, and Clone IAC 1 , also susceptible and obtained by somatic embryogenesis. Open-pollinated progeny showed segregation to resistance and was classified as susceptible according to the reproduction factor. The average number of nematodes (eggs and J2) per gram of roots in clones was eight fold lower than that of open-pollinated progeny, and 51 fold lower than Mundo Novo IAC 515-20. Based on Seinhorst model, IAC 3 clone showed a tolerance limit of 7.7 nematodes per $\mathrm{cm}^{3}$ of soil, while in Mundo Novo the tolerance limit was 3.9 nematodes per $\mathrm{cm}^{3}$ of soil. These results revealed that clonal Arabica coffee nematoderesistant trees represent an alternative to the time consuming and expensive process inherent to conventional breeding strategies.
\end{abstract}

Keywords: root-knot nematodes, resistant variety, somatic embryogenesis

\section{Introduction}

Root-knot nematodes (RKN) are a serious threat to coffee production worldwide and Meloidogyne paranaensis Carneiro et al. (1996) stands out among coffee parasitic species due to its aggressiveness and the losses caused to coffee plantation in Brazil, Guatemala, Hawaii and Mexico (Carneiro et al., 2004; Lopez-Lima et al., 2014; Villain et al., 2013).

Except for IPR 100 (Sera et al., 2017) and IPR 106 (Ito el al., 2008), most Coffea arabica L. cultivars are highly susceptible to $M$. paranaensis. Genetic resistance is the most effective method to cultivate coffee in infested soils (Bertrand and Anthony, 2008). Sources of resistance were identified in C. canephora Pierre ex A. Froehner (Bertrand et al., 2000; Sera et al., 2006), in wild Ethiopian C. arabica accessions (Anzueto et al., 2001; Boisseau et al., 2009; Fatobene et al., 2017), and in C. arabica germplasms derived from introgression of $C$. canephora genes, such as Timor Hybrid (Bertrand et al., 2001; Salgado et al., 2014) and in Icatu (Campos and Villain, 2005).

Icatu germplasm results from interspecific hybridization between $C$. canephora and $C$. arabica cultivar Bourbon Vermelho. Some plants of this germplasm were resistant to $M$. paranaensis in our field experiments. Icatu 925 is one of the most promising materials from the plant H4782-7-925. Despite the good performance of plants when compared with $C$. arabica cultivars, the interspecific origin of Icatu results in resistance segregation in progenies due higher cross-pollination rates in some individuals (Carvalho et al., 1983).

Genetic improvement of coffee through traditional methods is hampered because $C$. arabica is an alloteraploid and perennial species. Thus, clonal propagation of heterozygous genotypes of $C$. arabica represents an alternative for large-scale multiplication of plants that segregate for the characteristic of interest. Somatic embryogenesis is a valuable alternative to propagate high yielding $F_{1}$ hybrids (Bertrand et al., 2011) and plants resistant to leaf miner Leucoptera coffeella Guérin-Méneville and leaf rust Hemileia vastatrix Berkeley and Broome (Andreazi et al., 2015; Maciel, 2016; Mendonça et al., 2016).

In this work, we compare $M$. paranaensis reproduction in clones and sexual progenies of IAC 3, a coffee plant of Icatu IAC 925, as subsidy for the development of a clonal cultivar. We also investigated the effect of initial population levels of $M$. paranaensis on vegetative growth of IAC 3 and on susceptible control Mundo Novo 515-20.

\section{Materials and Methods}

\section{Resistance assessment in greenhouse conditions}

The plant IAC 3, of Icatu IAC 925, was selected as mother plant to produce clonal seedlings because it is resistant to $M$. paranaensis, highly productive and vigorous in infested fields. Clonal seedlings of IAC 3 were obtained via somatic embryogenesis and sexual progenies were obtained by seeds (open pollination). Two susceptible controls were used: $C$. arabica cultivar Mundo Novo IAC 515-20, obtained from seeds, and Clone IAC 1 , an $\mathrm{F}_{1}$ hybrid between the cultivars Icatu Vermelho IAC 4045 and Obatã IAC 1669-20, also propagated by somatic embryogenesis. Clone IAC 1, resistant to the coffee leaf rust and susceptible to $M$. paranaensis was included to assess the possible effects of somatic embryogenesis in root development, affecting the measurement of nematodes reproduction. 
Seedlings obtained by cloning and seeds with two pairs of leaves were transplanted to plastic pots of 500 $\mathrm{mL}$ containing a sterile mixture of sand and soil (1:1) fertilized with simple superphosphate and with a controlled release complex fertilizer (NPK 16-8-12). The soil was supplied with amounts of nutrients equivalent to $0.429 \mathrm{~kg}$ per $\mathrm{m}^{3}$ of $\mathrm{N}, 0.567 \mathrm{~kg}$ per $\mathrm{m}^{3}$ of $\mathrm{P}$ and $0.498 \mathrm{~kg}$ per $\mathrm{m}^{3}$ of $\mathrm{K}$.

The identification of $M$. paranaensis population, collected in Cássia dos Coqueiros, São Paulo State, Brazil, was performed by esterase phenotypes. Afterward, the nematodes were multiplied in pots containing susceptible C. arabica cultivar Mundo Novo IAC 515-20 and susceptible tomato Solanum lycopersicum L. cultivar Santa Cruz.

Inoculums were obtained according to Hussey and Baker (1973). Seedlings of four to six pair of leaves were inoculated with approximately 5,000 eggs and J2 per plant Experiment was arranged in a completely randomized design with 20 replicates and single-plant plots.

Damage to the root systems was evaluated 135 days after inoculation through the damage index (DI) and reproduction factor (RF). DI is scored according to a modified scale of Hussey and Jansen (2002) and Bertrand et al. (2000) where $0=$ totally intact root systems; $1=$ presence of rare and small swellings in secondary roots; 2 = small swellings of less than $25 \%$ of the root system; 3 = swellings and early necrosis of $25-50 \%$ of the root system; $4=$ loss of secondary roots due to necrosis observed in 51-75 \% of the root system; and $5=$ severe loss of secondary roots greater than $75 \%$ with destruction of the root system. Plants were considered resistant when DI $\leq 2$, and susceptible when DI $>2$.

Population was estimated by counting nematodes in Peters's slides under a light microscope, quantifying the eggs and juveniles of $M$. paranaensis. The final population (FP) corresponds to the number of nematodes extracted from the entire roots of each plant. The reproduction factor $(\mathrm{RF})$ was determined according to Oostenbrink (1966).

Number of eggs and J2 per gram of root (NEM) were calculated from the ratio between the size of the final nematode population and fresh root mass to quantify proportionally the number of nematodes per treatment. NEM data were $\log$ transformed $(\log 10(x+1))$, subjected to the analysis of variance (ANOVA) and the means were compared by the Scott-Knott test $(p<0.05)$.

\section{Effect of initial population levels of $M$. paranaensis on coffee plant development}

Seedlings of IAC 3, obtained by somatic embryogenesis, and susceptible control Mundo Novo IAC 51520 , obtained from seeds, were cultivated in a greenhouse in plastic pots of $1.7 \mathrm{~L}$ containing a sterile mixture of sand and soil (1:1), fertilized in the same way as the first experiment. Plants with five pairs of leaves were inoculated by the deposition of $M$. paranaensis suspension (eggs and juveniles) in holes made in the substrate around the plants. The inoculum concentration varied to obtain the initial population levels $(\mathrm{Pi})$ according to the six pre-established treatments $(0,0.7,1.5,2.9,5.9$ and 11.8 nematodes per $\mathrm{cm}^{3}$ of soil). The experiment was performed in a completely randomized design with nine replicates and single-plant plots.

After 345 days, the aerial parts of the plants were removed, stored in paper bags and dried in oven 160 $\left.{ }^{\circ} \mathrm{C}\right)$ to obtain the top dry weight (TDW). The root system of each plant was washed, the root fresh weight (RFW) was obtained and the nematodes were extracted according to the Hussey and Baker (1973). The final population (FP) and reproduction factor (RF) was estimated according the same procedures described for the first experiment.

The RFW data were analyzed according to the nonlinear model proposed by Seinhorst (1965), based on the equation: $\mathrm{Y}=\mathrm{m}+(1-\mathrm{m}) \cdot \mathrm{Z}^{\mathrm{Pi}-\mathrm{T}}$; in which, $\mathrm{Y}$ is the ratio of the estimated variable for plant growth in an initial population density of the nematode (PI) divided by the value obtained in the control plant; $\mathrm{m}$ is the minimum yield of the plant obtained under high population densities of the nematode; $Z$ is a constant less than $1(Z<1)$; $\mathrm{Pi}$ is the initial population density of the nematode and $\mathrm{T}$ is the tolerance limit. For the Seinhorst analysis, we used the SeinFit software, DOS version, developed by Viaene et al. (1997). Additionally, the experimental data were submitted to the principal component analysis (PCA) using Statistica 11 software. In the PCA, the reduction of top dry weight (RTDW) was obtained from the relation between the value of each treatment by the experimental control, according the equation: RTDW $=100$-(TDWt/ TDWc) ${ }^{*} 100$, where TDWt is the top dry weight of a treatment and TDWc is the top dry weight of the control.

\section{Results}

\section{Resistance assessment in greenhouse conditions}

Progeny IAC 3 was considered susceptible to $M$. paranaensis according $\mathrm{RF}$, on average, with a resistance segregation rate of $50 \%$ (Table 1), but its NEM was six fold lower and statistically different from the susceptible control Mundo Novo IAC 515-20. Conversely, clone IAC 3 revealed a reduced mean of RF and NEM and, as expected, all replicates were resistant to $M$. paranaensis $(\% \mathrm{R}=100)$. Susceptible control Mundo Novo IAC 51520 , obtained by seeds, and Clone IAC 1 , propagated by somatic embryogenesis, showed high RF means and 100 $\%$ of susceptible plants (Table 1 ).

\section{Effect of initial population levels of $M$. paranaensis on coffee plant development}

The reproduction factor for each inoculum density tested in both coffee seedlings are presented in Table 2. With the increase of nematode density, there was a reduction in RF. For example, in Mundo Novo, the RF value at the lowest density was 44.1 , while at the highest nematode density, this value was 1.2 ; thus, regardless of 
the Pi level, Mundo Novo was considered susceptible. Conversely, IAC 3 was considered resistant, as RF was 0.35 at the lowest density and 0.06 at the highest.

The results obtained with the Seinhorst nonlinear model (Figure 1) showed that Mundo Novo plants, adjusted the equation as follows: $\mathrm{Y}=0.250+(0.75) \cdot 1^{\mathrm{Pi}-}$ 3.9. The value found for the tolerance limit $(\mathrm{T})$ was 3.9 nematodes per $\mathrm{cm}^{3}$ of soil; therefore, plants began to suffer damage caused by $M$. paranaensis at this population density. There was also a reduction of $75 \%$ of RFW (m $=0.250$ ), demonstrating the severity of damages caused by $M$. paranaensis in $C$. arabica cv Mundo Novo.

Conversely, for plants from clonal seedlings IAC 3 , the equation was as follows: $\mathrm{Y}=0.900+(0.10) \cdot 1^{\mathrm{Pi}-7.7}$, where $\mathrm{T}$ was 7.7 nematodes per $\mathrm{cm}^{3}$ of soil, and the $\mathrm{m}$ value was 0.900 , indicating that IAC $3 \mathrm{RFW}$ was only reduced by an average of $10 \%$ in response to nematode infection, clearly demonstrating that IAC 3 plants were more tolerant to nematode attack than Mundo Novo.

According to PCA (Figure 2), $90 \%$ of the total variability is explained by the axes 'varietal resistance' 160 $\%)$ and 'vegetative development' $(30 \%)$ of plants. Vari-

Table 1 - Damage index (DI), number of eggs and J2 per gram of roots (NEM), reproduction factor (RF), phenotype and percentage of resistant plants according reproduction factor (\% R) in coffee trees inoculated with Meloidogyne paranaensis.

\begin{tabular}{|c|c|c|c|c|}
\hline Treatment & $\mathrm{Dl}^{\mathrm{a}}$ & $\mathrm{NEM}^{\mathrm{b}}$ & RF & $\% \mathrm{R}$ \\
\hline Progeny IAC 3 & 2.3 & $2,487 b$ & 2.5 & 50 \\
\hline Clone IAC 3 & 1.4 & $291 \mathrm{C}$ & 0.2 & 100 \\
\hline Clone IAC $1^{* *}$ & 4.3 & $11,575 \mathrm{a}$ & 12.5 & 0 \\
\hline Mundo Novo IAC 515-20** & 4.2 & 14,826 a & 11.9 & 0 \\
\hline $\mathrm{CV}(\%)=44$ & & & & \\
\hline
\end{tabular}

Table 2 - Effect of Meloidogyne paranaensis initial population (Pi) on the root fresh weight (RFW) of coffee plants Mundo Novo and IAC 3, final nematode population (FP), reproduction factor (RF) and plant phenotype, 345 days after inoculation.

\begin{tabular}{lccrcc}
\hline Treatment & $\mathrm{Pi}$ & $\mathrm{RFW}$ & \multicolumn{1}{c}{ FP } & RF & Phenotype $^{* *}$ \\
\hline & 0 & 32.02 & 0.0 & 0.0 & - \\
Mundo Novo IAC 515-20 & 0.74 & 25.68 & 55166.7 & 44.13 & $\mathrm{~S}$ \\
& 1.47 & 27.67 & 54500.0 & 21.80 & $\mathrm{~S}$ \\
& 2.90 & 28.05 & 61388.9 & 12.28 & $\mathrm{~S}$ \\
& 5.90 & 24.49 & 30833.3 & 3.08 & $\mathrm{~S}$ \\
& 11.8 & 19.40 & 23944.4 & 1.20 & $\mathrm{~S}$ \\
\hline \multirow{3}{*}{ Clone IAC 3 } & 0 & 29.28 & 0.0 & 0.0 & - \\
& 0.74 & 30.58 & 444.4 & 0.35 & $\mathrm{R}$ \\
& 1.47 & 29.26 & 611.1 & 0.24 & $\mathrm{R}$ \\
& 2.90 & 30.28 & 166.7 & 0.43 & $\mathrm{R}$ \\
\hline & 5.90 & 33.36 & 555.6 & 0.06 & $\mathrm{R}$ \\
\hline
\end{tabular}

${ }^{*} \mathrm{R}=$ resistant and $\mathrm{S}=$ susceptible to $M$. paranaensis; $\mathrm{Pi}=$ Number of eggs $+\mathrm{J} 2$ per $\mathrm{cm}^{3}$ of soil; $\mathrm{FP}=$ Number of eggs $+\mathrm{J} 2$. etal resistance was explained by DI, FP, NEM and RF variables and vegetative development, by RFW, TDW and RTDW variables.

Regardless of the initial level of the inoculum, coffee trees of clone IAC 3 form a cluster to the left of the $\mathrm{X}$ axis, revealing a high level of varietal resistance to nematode $M$. paranaensis (Figure 1). The cultivar Mundo Novo IAC 515-20 presented high mean values of the variables DI, FP, NEM and RF, susceptible to $M$. paranaensis. However, influence of the initial level of inoculum on the vegetative development of the plants was lower when inoculated with 5.9 and 11.8 nematodes per $\mathrm{cm}^{3}$ of soil (Figure 2).

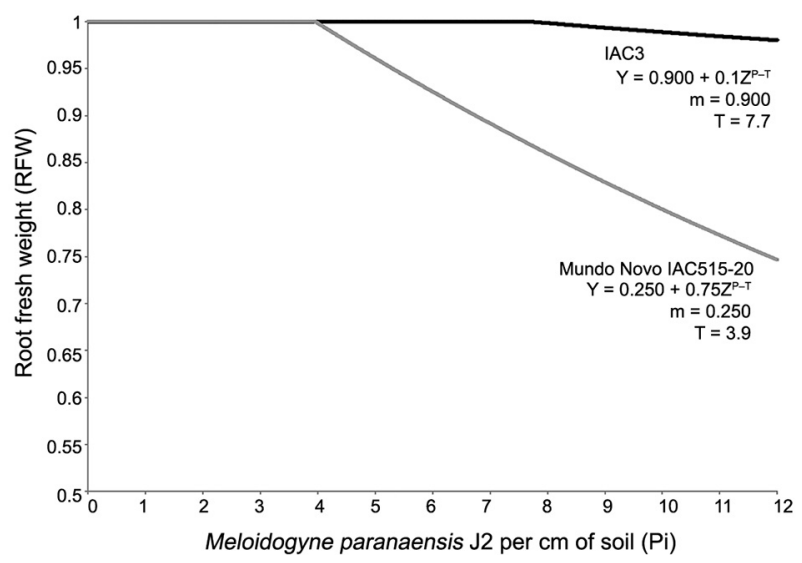

Figure 1 - Relationship between Meloidogyne paranaensis initial population (Pi) and the root fresh weight of coffee plants IAC 3 and Mundo Novo IAC 515-20, 345 days after inoculation.

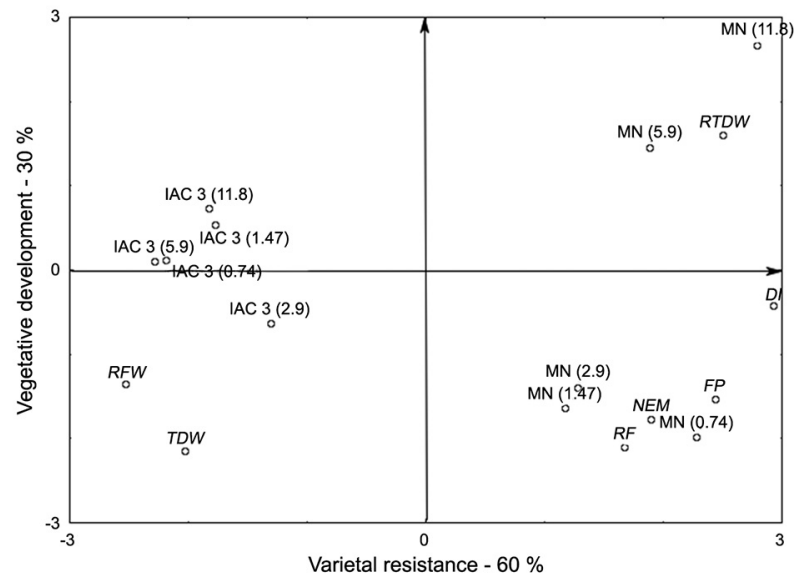

Figure 2 - Principal component analysis. Varietal resistance $(60$ $\%)$ and vegetative development (30\%) of plants from clone IAC 3 and cultivar Mundo Novo IAC 515-20 inoculated with 0.74, 1.47, 2.9, 5.9 and 11.8 nematodes per $\mathrm{cm}^{3}$ of soil and relationship among damage index (DI), root fresh weight (RFW), final population (FP), number of nematodes, eggs and J2 per gram of root (NEM), reproduction factor (RF), top dry weight (TDW) and reduction of top dry weight (RTDW) variables. 


\section{Discussion}

Coffea arabica is an autogamous and tetraploid species with self-fertilization rate of about $90 \%$ (Carvalho and Krug, 1949) and its cultivars are commercially propagated by seeds. Breeding programs aim to select uniform cultivars for all agronomic traits; however, it is a lengthy procedure that involves several selection cycles. This process is more complex when it involves the resistance genes introgression of diploid and allogamous species, such as $C$. canephora. Therefore, genetic resistance of IAC 3 to $M$. paranaensis found in segregating progenies could be immediately explored using clonal coffee trees. Multiplication of resistant plants via somatic embryogenesis is a promising tool for largescale production, shortening the time to obtain a resistant cultivar, besides eliminating the fixation step of resistance genes. In field conditions, coffee clones from seeds have similar performance of traditional seedlings and do not have limitations for commercial use (Etienne and Bertrand, 2001).

Despite the higher production cost, aggregated value of clonal seedlings resistant to RKN may compensate farmer's investment in infested areas. To address this question, several works have been conducted to increase efficiency of somatic embryogenesis protocols and to reduce production costs of clonal seedlings (Etienne et al., 2012; Etienne et al., 2013; Maciel et al., 2016).

Considering the analysis of the effect of initial population levels of $M$. paranaensis on IAC 3 and Mundo Novo development, several greenhouse experiments have shown the relationships between coffee and Meloidogyne spp based on the Seinhorst model. Vovlas and Di Vito (1991) reported that the tolerance limit was two eggs per $\mathrm{cm}^{3}$ of soil of $M$. javanica and $M$. incognita, on C. arabica cultivar São Tomé. Also, Zhang and Schmitt (1995) demonstrated that the shoot and root growth of $C$. arabica cultivars SL28, Guatemalan, Mundo Novo, Bourbon Vermelho and Guadalupe were suppressed by $M$. konaensis. The authors calculated the threshold to be a little less than 10 eggs per plant. Di Vito et al. (2000) observed the reduction in the seedling of São Tomé caused by $M$. exigua. The tolerance limit for the variable shoot weight was 1.2 eggs and J2 per $\mathrm{cm}^{3}$ of soil. However, there is paucity of information regarding the relationship of $M$. paranaensis population densities to coffee growth.

For Souza and Bressan-Smith (2007), threshold levels can only demonstrate the potential of damage caused to seedlings under greenhouse conditions and cannot be used to predict any damage to coffee production in the field. However, our results showed that clonal seedlings (IAC 3) were actually more tolerant to M. paranaensis attack than Mundo Novo plants. IAC 3 demonstrated a tolerance limit of 7.7 nematodes per $\mathrm{cm}^{3}$ of soil (equivalent to a $\mathrm{Pi}$ of 13090 nematodes per plant), while in Mundo Novo IAC515-20 the tolerance limit was 3.9 nematodes per $\mathrm{cm}^{3}$ of soil (equivalent to a $\mathrm{Pi}$ of 6588 nematodes per plant). Thus, IAC 3 clone showed higher level of tolerance as it resisted nematode attack better than Mundo Novo plants.

If threshold levels (Figure 1) are considered only for studies conducted in greenhouse conditions, the PCA results reveal that the clonal seedlings are always resistant to $M$. paranaensis regardless of the initial nematode population in the soil (Figure 2). This resistance reaction of young plants of Clone IAC 3 to high nematode population levels is of outstanding practical importance, since coffee growers rarely adopt practices to reduce nematode population levels in infested soils before planting.

\section{Acknowledgments}

The authors are grateful to Consórcio Brasileiro de Pesquisa e Desenvolvimento do Café (CBP and D-Café) (project 002.06.10.014.00.03: Evaluation of coffee plants resistant to Meloidogyne spp. in infested areas of São Paulo State.); Conselho Nacional de Desenvolvimento Científico e Tecnológico (CNPq) for research fellowship (OGF CNPq DT 308.634/2016-0); Fundação de Amparo à Pesquisa do Estado de São Paulo (FAPESP) for scholarship (BJRF FAPESP 2010/15416-0) and Dra. Mirian Perez Maluf for helpful comments and suggestions.

\section{Authors' Contributions}

Conceptualization: Gonçalves, W.; Fatobene, B.J.R. Data acquisition: Gonçalves, W.; Fatobene, B.J.R. Data analysis: Fatobene, B.J.R.; Guerreiro Filho, O.; Oliveira, C.M.G. Design of Methodology: Gonçalves, W.; Fatobene, B.J.R. Writing and editing: Fatobene, B.J.R.; Guerreiro Filho, O.; Oliveira, C.M.G.

\section{References}

Andreazi, E.; Sera, G.H.; Faria, R.T.; Sera, T.; Shigueoka, L.H.; Carvalho, F.G.; Carducci, F.C.; Chamlet, D. 2015. Desempenho de híbridos $\mathrm{F}_{1}$ de café arábica com resistência simultânea a ferrugem, mancha aureolada e bicho mineiro. Coffee Science 10: 375-382 (in Portuguese).

Anzueto, F.; Bertrand, B.; Sarah, J.L.; Eskes, A.B.; Decasy, B. 2001. Resistance to Meloidogyne incognita in Ethiopian Coffea arabica accessions. Euphytica 118: 1-8.

Bertrand, B.; Peña Durán, M.X.; Anzueto, F.; Cilas, C.; Etienne, H.; Anthony, F.; Eskes, A.B. 2000. Genetic study of Coffea canephora coffee tree resistance to Meloidogyne incognita nematodes in Guatemala and Meloidogyne sp. nematodes in El Salvador for selection of rootstock varieties in Central America. Euphytica 113: 79-86.

Bertrand, B.; Anthony, F.; Lashermes, P. 2001. Breeding for resistance to Meloidogyne exigua in Coffea arabica by introgression of resistance genes of Coffea canephora. Plant Pathology 50: 637-643. 
Bertrand, B.; Anthony, F. 2008. Genetics of resistance to rootknot nematodes (Meloidogyne spp.) and breeding. p. 165-190. In: Souza, R.M., ed. Plant-parasitic nematodes of coffee. APS Press, St. Paul, MN, USA.

Bertrand, B.; Alpizar, E.; Lara, L.; SantaCreo, R.; Hidalgo, M.; Quijano, J.M.; Montagnon, C.; Georget, F.; Etienne, H. 2011. Performance of Coffea arabica $\mathrm{F}_{1}$ hybrids in agroforestry and full-sun cropping systems in comparison with American pure line cultivars. Euphytica 181: 147-158.

Boisseau, M.; Aribi, J.; Sousa, F.R.; Carneiro, R.M.D.G.; Anthony, F. 2009. Resistance to Meloidogyne paranaensis in wild Coffea arabica. Tropical Plant Pathology 34: 38-41.

Campos, V.P.; Villain, L. 2005. Nematode parasites of coffee, cocoa and tea. p. 529-579. In: Luc, M.; Sikora, R.A.; Bridge, J., eds. Plant parasitic nematodes in subtropical and tropical agriculture. CAB International, Wallingford, UK.

Carneiro, R.M.D.G.; Carneiro R.G.; Abrantes, M.O.; Santos, M.S.N.A.; Almeida, M.R. A. 1996. Meloidogyne paranaensis n. sp. (Nemata: Meloidogynidae), a root-knot nematode parasitizing coffee in Brazil. Journal of Nematology 28: 177189.

Carneiro, R.M.D.G.; Tigano, M.S.; Randig, O.; Almeida, M.R.A.; Sarah, J.L. 2004. Identification, characterization and diversity of Meloidogyne spp. (Tylenchida, Heteroderidae) on coffee from Brazil, Central America and Hawaii. Nematology 6: 287-298.

Carvalho, A.; Krug, C.A. 1949. Agents of pollination of coffee flower (Coffea arabica L.) Bragantia 9: 11-24. (in Portuguese, with abstract in English).

Carvalho, A.; Costa, W.M.; Fazuoli, L.C. 1983. Self-compatibility, yield, peaberry seed an abnormal seedlings In Icatu coffee populations. Bragantia 42: 157-169 (in Portuguese, with abstract in English).

Di Vito, M.; Crozzoli, R.; Vovlas, N. 2000. Pathogenicity of Meloidogyne exigua on coffee (Coffea arabica L.) in pots. Nematropica 30: 55-61.

Etienne, H.; Bertrand, B. 2001. Trueness-to-type and agronomic characteristics of Coffea arabica trees micropropagated by the embryogenic cell suspension technique. Tree Physiology 21: 1031-1038.

Etienne, H.; Bertrand, B.; Montagnon, C.; Bobadilla Landey, R.; Dechamp, E. 2012. An example of successful technology transfer in micropropagation: the multiplication of Coffea arabica by somatic embryogenesis. Cahiers Agricultures 21: 115-24.

Etienne, H.; Bertrand, B.; Georget, F.; Lartaud, M.; Montes, F.; Dechamp, E.; Verdeil, J.L.; Barry-Etienne, D. 2013. Development of coffee somatic and zygotic embryos to plants differs in the morphological, histochemical and hydration aspects. Tree Physiology 33: 640-653.

Fatobene, B.J.R.; Andrade, V.T.; Aloise, G.S.; Silvarolla, M.B.; Gonçalves, W.; Guerreiro Filho, O. 2017. Wild Coffea arabica resistant to Meloidogyne paranaensis and genetic parameters for resistance. Euphytica 213: 1-9.

Hussey, R.S.; Barker, K.R. 1973. A comparison of methods of collecting inocula of Meloidogyne spp. including a new technique. Plant Disease Report 57: 1025-1028.
Hussey, R.S.; Janssen, G.J.W. 2002. Root-knot nematode: Meloidogyne species. p. 43-70. In: Starr, J.L.; Cook, R.; Bridge, J., eds. Plant resistance to parasitic nematodes. CAB International, Wallingford, UK.

Ito, D.S.; Sera, G.H.; Sera, T.; Santiago, D.C.; Kanayama, F.S.; Del Grossi, L. 2008. Progenies of coffee with resistance to nematodes MeloidogyneParanaensis and Meloidogyne Incognita race 2. Coffee Science 3: 156-163 (in Portuguese, with abstract in English).

Lopez-Lima, D.; Sánchez-Nava, P.; Carrion, G.; Monteros, A.E.; Villain, L. 2014. Corky-root symptoms for coffee in central Veracruz are linked to the root-knot nematode Meloidogyne paranaensis, a new report for Mexico. European Journal of Plant Pathology 141: 623-629.

Maciel, A.L.R.; Rodrigues, F.A.; Pasqual, M.; Carvalho, C.H.S. 2016. Large-scale, high-efficiency production of coffee somatic embryos. Crop Breeding and Applied Biotechnology 16: 102107.

Mendonça, A.P.; Nonato, J.V.A.; Andrade, V.T.; Fatobene, B.J.R.; Braghini, M.T.; Prela-Pantano, A.; Guerreiro Filho, O. 2016. Coffea arabica clones resistant to coffee leaf miner. Crop Breeding and Applied Biotechnology 16: 42-47.

Oostenbrink, M. 1966. Major characteristics of the relation between nematodes and plants. Mededelingen van de Landbouwhogeschool te Wageningen, 66: 1-46.

Salgado, S.M.L.; Rezende, J.C.; Nunes, J.A.R. 2014. Selection of coffee progenies for resistance to nematode Meloidogyne paranaensis in infested area. Crop Breeding and Applied Biotechnology 14: 94-101.

Sera, G.H.; Sera, T.; Azevedo, J.A.; Mata, J.S.; Ribeiro Filho, C.; Doi, D.S.; Ito, D.S. Fonseca, I.C.B. 2006. Robusta coffee rootstocks resistants to Meloidogyne paranaensis and $M$. incognita races 1 and 2. Semina: Ciências Agrárias 27: 171-184.

Sera, T.; Sera, G.H.; Fazuoli, L.C.; Machado, A.C.Z.; Ito, D.S.; Shigueoka, L.H.; Silva, S.A. 2017. IPR 100: rustic dwarf Arabica coffee cultivar with resistance to nematodes Meloidogyne paranaensis and M. incognita. Crop Breeding and Applied Biotechnology 17: 175-179.

Souza, R.M.; Bressan-Smith, R. 2008. Coffee-associated Meloidogyne spp. ecology and interaction with plants. p. 123147. In: Souza, R.M., ed. Plant-parasitic nematodes of coffee. APS Press, St. Paul, MN, USA.

Viaene, N.M.; Simoens, P.; Abawi, G.S. 1997. Seinfit, a computer program for the estimation of the Seinhorst equation. Journal of Nematology 29: 474-477.

Villain, L.; Sarah, J.L.; Hernández, A.; Bertrand, B.; Anthony, F.; Lashermes, P.; Charmetant, P.; Anzueto, F.; Carneiro, R.M.D.G. 2013. Diversity of root-knot nematodes parasiting coffee in Central America. Nematropica 43: 194-206.

Vovlas, N.; Di Vito, M. 1991. Effect of root-knot nematodes Meloidogyne incognita and M. javanica on the growth of coffee (Coffea arabica L.) in pots. Nematologia Mediterranea 19: 253258.

Zhang, F.; Schmitt, D.P. 1995. Relationship of Meloidogyne konaensis population densities to coffee growth. Plant Disease 79: 446-449. 